\title{
Cultural Integration on Students' Productivity During Distance Learning
}

\author{
Parmin $^{1 *}$, Mohammad Qois Syafi², Iwan Junaedi ${ }^{3}$, Agus Yulianto4, Eling Purwantoyo5, \\ Ibnul Mubarok ${ }^{4}$ iD \\ ${ }^{1}$ Integrated Science Study Program, Universitas Negeri Semarang, Indonesia \\ ${ }^{2}$ Computer Science Study Program, Universitas Negeri Semarang, Indonesia \\ ${ }^{3}$ Mathematics Education Study Program, Universitas Negeri Semarang, Indonesia \\ ${ }^{4}$ Physics Education Study Program, Universitas Negeri Semarang, Indonesia \\ ${ }^{5}$ Biology Educiation Study Program, Universitas Negeri Semarang, Indonesia \\ *Corresponding author: parmin@mail.unnes.ac.id
}

\begin{abstract}
This study aims to measure the effectiveness of cultural integration on the productivity of Mathematics and Natural Sciences students during the implementation of distance learning. The culture integrated into this research is a habit that becomes a society's tradition in behaving. The research problem is about the integration of culture on character formation, which impacts student productivity. The study used mixed methods with quantitative data from questionnaires and qualitative data from interviews and document analysis. The research targets are Mathematics and Natural Science students from 6 majors, class of 2020, at Universitas Negeri Semarang. 344 students filled out the questionnaire. After the questionnaire data was analyzed, it was deepened through interviews. The relationship test between character strengthening and students' productivity obtained a correlation coefficient value of 0.59 , indicating that the correlation between variables is quite strong. Internalization of cultural values into forming students' characters in distance lectures and activities is carried out through habituation. The selection of online application media refers to the ease of access, students' common use, and ease of operation. The research concludes that students' characters contribute to building students' self-awareness to be productive.
\end{abstract}

Keywords: culture; character; productivity; students

\begin{tabular}{|c|c|c|}
\hline History: & & Publisher: Undiksha Press \\
\hline Received & : August 24, 2021 & Licensed: This work is licensed under \\
\hline Revised & : September 01, 2021 & a Creative Commons Attribution 3.0 License \\
\hline Accepted & : September 30, 2021 & (c) (1) (D) \\
\hline Published & : October 25, 2021 & $0 \mathrm{EY}_{\mathrm{SA}}$ \\
\hline
\end{tabular}

\section{INTRODUCTION}

Social culture, such as habits, ethics, and norms, is integrated into forming students' soft skills (Winther-Lindqvist, 2020). Integrating culture through activities that sharpen students' soft skills has become an ongoing routine program for Mathematics and Natural Science students at Universitas Negeri Semarang. Activities are carried out through seminars, public lectures, training, workshops, focus group discussions, research, and community service. As activities are not enough to form strong students' characters, it is necessary to test the impact to measure students' characters. Follow-up of various activities and results is by measuring the actual impact on students' productivity. The characters of pre-service teachers are not limited to attitudes but to learning outcomes, including the impact on students' productivity (Darma et al., 2018; Suhaida \& Idham, 2018; Wayan, 2020). Students' productivity is expected to strengthen along with strengthening students' characters.

Internalization of social culture or tradition into the education system in higher education is part of the effort to prepare prospective graduates who can be accepted into society (Chen et al., 2019). The purpose of the students' character strengthening program is not limited to attitudes but to build awareness of productive behavior because the demands of the world of work today are not limited to competence but character (Amran et al., 2020; Nurtanto et al., 2020; Serbin et al., 2020). The need for human resources in industry, 
government, and private institutions for university graduates requires information about the character of prospective employees (Hasanah, 2013; Wahab, 2016). There are concerns from campus administrators about students' politeness in communicating in lectures and extracurricular activities. Students as millennials who actively use social media through WhatsApp, Facebook, Instagram, and Twitter need to be equipped with communication ethics that are not only polite but legally literate (Awidi et al., 2019; Mulyono et al., 2021). Students' awareness of legal literacy is still weak. It can be seen from the likes or comments they give on provocative news and even hoaxes.

Attitudes and behaviors are formed through daily habituation on campus, in face-toface and online activities such as during the Covid-19 pandemic. The habituation program through the internalization of social culture becomes a programmed and measurable pattern of forming characters (Fahmy et al., 2015; Suastra et al., 2017). Research state that various activities to strengthen students' characters in universities impact students' daily habits on campus (Choli, 2020; Wahono, 2018). An activity is not enough to strengthen character because it is difficult to measure the resulting impact. Measurement of students' character can be done by self-assessment and assessing others (Hulukati \& Maryam, 2020). Assessment of a person's character is obtained through the others' observations so that other parties are needed to assess. Character is easy to guide but difficult to measure. Character measurement is needed to guide policymaking and measure the success of the guidance carried out (Lestari \& Harjono, 2021; Sutijan et al., 2015).

The challenge of strengthening students' character during the Covid-19 pandemic is increasingly complex due to the impact of distance learning (Ibnu \& Syukri, 2021; Monitorir, 2020). However, character strengthening still must be done, especially in distance learning situations. The analysis of the research results published in various journals described in this section reinforces the importance of finding strategies to form students' characters that raise awareness to strengthen their productivity. Learning oriented towards a social scientific approach by integrating examples of scientific application in social life can develop character (Kim, G., Ko \& Lee, 2020). Students activities that continuously and seriously train politeness, discipline, and responsibility can shape students' character (Abdullah et al., 2015; Susanti, 2013). Character forming for students does not stop at good attitudes but is expected to impact productivity positively (Abdullah et al., 2015; Nisa \& Wuryandani, 2018). Innovation is needed in various content to strengthen character, one of which is teaching materials oriented to students' characters.

Integrating teaching materials with social culture can be an option in strengthening characters (Göthberg, 2019; Hartini, S. et al., 2018). There is an increase in learning interest when it is associated with strengthening character because it encourages positive thinking about learning materials (Harzer, 2016; Lavy, 2019). Students' character-forming through habituation can be pursued through lecture activities (Fitriani, 2019; Ningsih \& Maulida, 2019). The students' character strengthening activities are effectively carried out through lecture activities that integrate character in content and material delivery (Taufiqurrahman, 2018). Presenting material that emphasizes contextual learning and using authentic assessment strategies to strengthen students' characters (Nurgiyantoro \& Anwar, 2013). The results of previous studies further enhance the importance of students' characters in distance learning. Distance learning must prioritize contextual studies because it has the holistic nature of learning by utilizing experience in the natural environment to make learning more useful (Bervell \& Arkorful, 2020; Stojanović et al., 2021; Warsito et al., 2016).

Character strengthening in the lecture process can be intensified in service learning so that the program will be more systematic and measurable (Handoyo, 2014). Besides being formed, the achievements of characters have to be measured. Unfortunately, most character strengthening programs are still limited to actions. The character assessment is not yet 
completed. Character measurement during distance learning can be done by providing online instruments that students can access and fill out. The culture integrated into this research is a habit that becomes society's tradition in behaving. Politeness in speaking, acting, dressing and several good habits in society are used to strengthen students' character. The productivity referred to in this study is the learning achievement index, delegation of competitions and activities, and participation in student organizations (Amran et al., 2020; Nurtanto et al., 2020). The rationale of the research is that when students have character, they raise awareness to work and achieve. The form of cultural integration on students' character and productivity is shown in Picture 1.

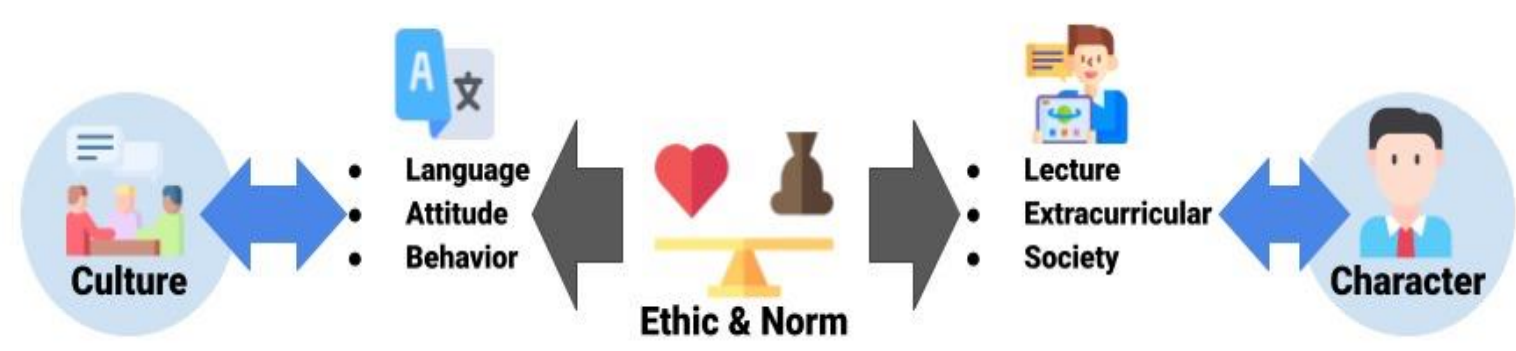

Picture 1. Cultural Integration on Students' Character and Productivity

This study aims to measure the effectiveness of cultural integration on the productivity of Mathematics and Natural Sciences students during distance learning. The main orientation is students' character-forming through the internalization of social culture tested as norms and social ethics in daily life. The students' characters formed since their studies will build a conducive academic and competitive climate so that they are expected to have a good image in the society and prospective users of graduates. The impact of students' character is students' character index as part of the graduate document in the certificate accompanying diploma. Information of students with character is expected to increase the acceptance of graduates in the world of work and society. Research about characters is needed on an ongoing basis to improve the competitiveness of graduates.

\section{METHODS}

The study used mixed methods, referring to (Creswell \& Pioano Clark, 2007). Quantitative data were from questionnaires, and qualitative data were from interviews and document analysis. The research stages include compiling students' self-assessment questionnaire instruments, compiling interview instruments, validating instruments, developing online assessment systems, collecting data, and analyzing research data. The research targets are Mathematics and Natural Science students from 6 majors, class of 2020, at Universitas Negeri Semarang. 344 students filled out the questionnaire. After the questionnaire data was analyzed, it was deepened through interviews. Document analysis was obtained through students' social media searches. A research framework that describes what has been and what will be done during the research, from the initial stages of the preliminary study, outputs, and targeted achievement indicators, is shown in Picture 2. 


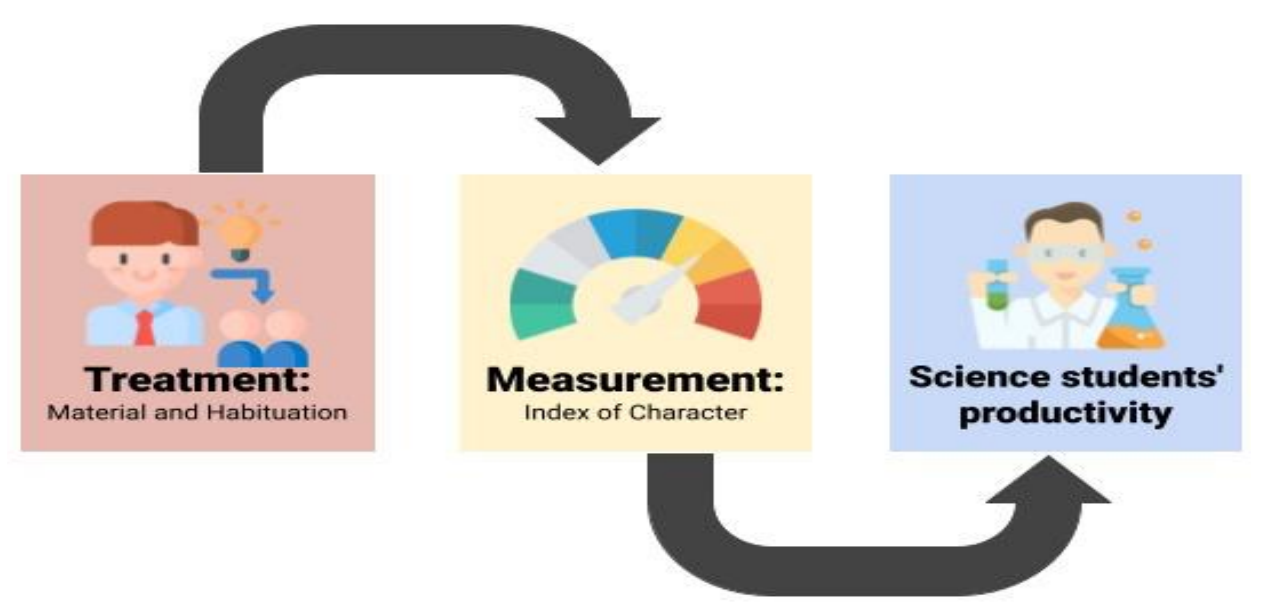

Picture 2. Research Framework

The data collection method is through students filling out online instruments via the website https://mipa.unnes.ac.id/v3/penilaian-diri-mahasiswa/. The character index instrument is determined from 10 items: habituation of prayer, the language of communication, social media, discipline, guardianship, radicalism, drugs, cheating, conservation, and prayer at the end of the lecture. There are four answer choices (strongly agree, agree, disagree, and strongly disagree). The questionnaire was filled out online so that it was inevitable that other students did not influence the respondents. The document analysis was to analyze the sample of the use of language in research targets' contents on WhatsApp, Facebook, Instagram, and Twitter. The data were analyzed linguistically, and the contents got the percentage that belongs to the category of polite/kind uploads, hate speech, and hoaxes. The findings of the social media analysis were triangulated with the results of questionnaires and interviews. A correlation test was conducted to determine the relationship between strengthening students' characters and students' productivity. The test was carried out using the Statistical Package for the Social Sciences (SPSS) program.

\section{RESULTS AND DISCUSSION}

\section{Result}

The self-assessment was carried out online with 344 students. The data is presented in Table 1.

Table 1. Self-assessment of students' character

\begin{tabular}{|c|c|c|c|c|}
\hline \multirow[b]{2}{*}{ Aspects of Character } & \multicolumn{4}{|c|}{ Score } \\
\hline & $\begin{array}{l}\text { Strongly } \\
\text { Agree }\end{array}$ & Agree & Disagree & $\begin{array}{l}\text { Strongly } \\
\text { Disagree }\end{array}$ \\
\hline I pray when I start a lecture & 216 & 128 & - & - \\
\hline $\begin{array}{l}\text { I always use good Bahasa to } \\
\text { communicate with my lecturer }\end{array}$ & 134 & 210 & - & - \\
\hline I use polite language on social media & 130 & 208 & 4 & 2 \\
\hline $\begin{array}{l}\text { I am always present on time for offline } \\
\text { and online lectures }\end{array}$ & 149 & 187 & 6 & 2 \\
\hline $\begin{array}{l}\text { I actively follow guidance from the } \\
\text { academic advisor }\end{array}$ & 106 & 214 & 19 & 5 \\
\hline I do not follow radicalism & 236 & 108 & - & - \\
\hline I am not a drug user & 289 & 55 & - & - \\
\hline
\end{tabular}




\begin{tabular}{lcccc}
\hline \multicolumn{1}{c}{ Aspects of Character } & \multicolumn{3}{c}{ Score } & \\
\cline { 2 - 5 } & $\begin{array}{c}\text { Strongly } \\
\text { Agree }\end{array}$ & Agree & Disagree & $\begin{array}{c}\text { Strongly } \\
\text { Disagree }\end{array}$ \\
\hline $\begin{array}{l}\text { I do not copy other's work in every } \\
\text { preparation of scientific work }\end{array}$ & 112 & 216 & 13 & 3 \\
$\begin{array}{l}\text { I, as a conservation cadre, implement } \\
\text { conservation values }\end{array}$ & 87 & 238 & 19 & - \\
I pray when I end a lecture & 145 & 174 & 23 & 2 \\
\hline
\end{tabular}

Four out of the ten aspects of cultural values are integrated into the habituation of students' characters: pray at the beginning of the activity, be polite in communication and social media, and pray at the end of the activity. The data for the answer choices agree and strongly agree with the four social cultures integrated into students' character-forming are presented in Picture 3. Students' productivity due to character strengthening in this study includes students' achievement index, competition delegation, activity delegation, and activeness in student organizations. The four primary data for determining the level of students' productivity are in Picture 4.

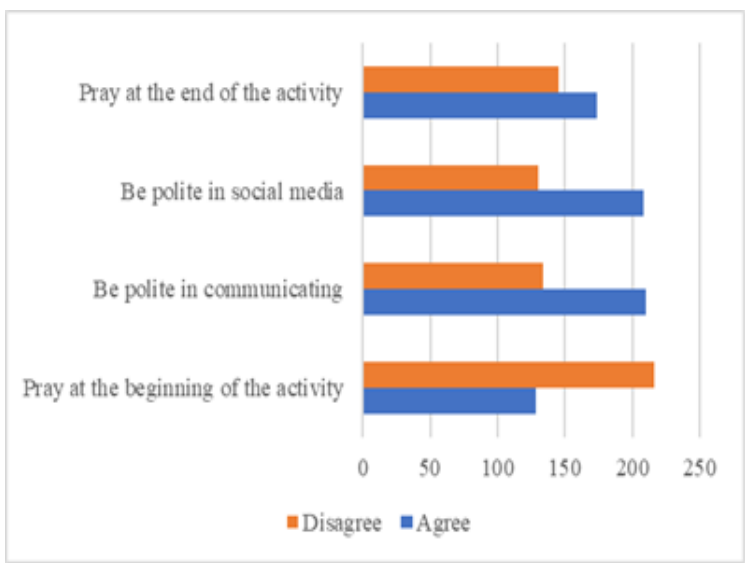

Picture 3. Assessment Results of Cultural Integration in Students' Character

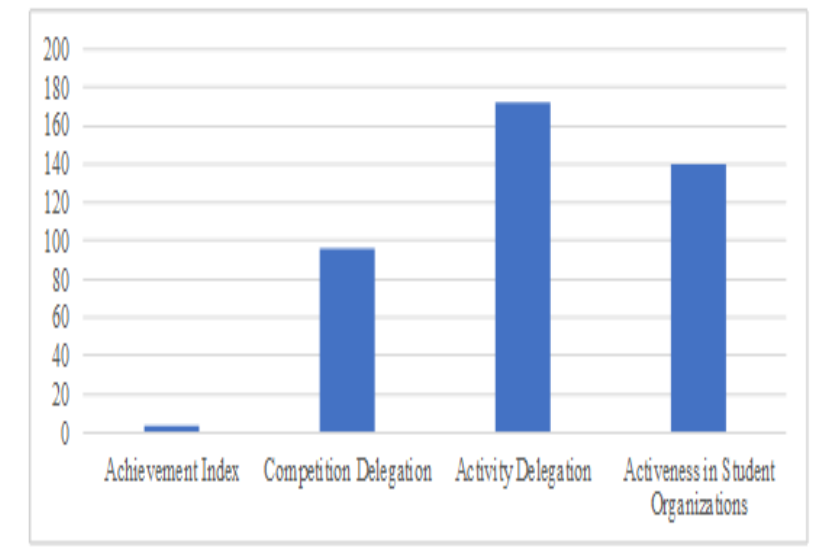

Picture 4. Students' Productivity

The relationship test between character strengthening and students' productivity obtained a correlation coefficient value of 0.59 , indicating that the correlation between variables is quite strong. This research is limited to the level of relationship between the two variables. However, in this study, no hypothesis test was carried out so that the significance of the relationship between the two variables was not analyzed. In-depth interviews with research targets are required to know the analysis result of questionnaire data, students' productivity, and the relationship between character strengthening and productivity. The results of the interviews are presented in Table 2.

Table 2. Interview Results

\begin{tabular}{lll}
\hline \multicolumn{1}{c}{ Questions } & \multicolumn{1}{c}{ Respondents' Answers } & \multicolumn{1}{c}{ Conclusion } \\
\hline $\begin{array}{l}\text { I feel the benefits of the } \\
\text { character program } \\
\text { conducted by campus } \\
\text { managers. }\end{array}$ & $\begin{array}{l}\text { The habituation to behave politely } \\
\text { based on Indonesian culture, which } \\
\text { is constantly reminded to students, } \\
\text { makes good habits that need to be } \\
\text { continued. }\end{array}$ & $\begin{array}{l}\text { Students feel the } \\
\text { benefits. }\end{array}$ \\
\hline
\end{tabular}




\begin{tabular}{|c|c|c|}
\hline Questions & Respondents' Answers & Conclusion \\
\hline $\begin{array}{l}\text { I am more aware of getting a } \\
\text { high achievement index. }\end{array}$ & $\begin{array}{l}\text { There is a strong desire to get high } \\
\text { grades in courses, but sometimes } \\
\text { there is limited ability. }\end{array}$ & $\begin{array}{l}\text { Students' awareness of } \\
\text { achievement is } \\
\text { strengthened. }\end{array}$ \\
\hline $\begin{array}{l}\text { I participate in competition } \\
\text { delegations. }\end{array}$ & $\begin{array}{l}\text { There is a desire to participate in } \\
\text { competitions according to interests } \\
\text { and talents, but some have not } \\
\text { achieved it. }\end{array}$ & $\begin{array}{l}\text { It encourages the desire } \\
\text { to compete. }\end{array}$ \\
\hline $\begin{array}{l}\text { I participate in activity } \\
\text { delegations. }\end{array}$ & $\begin{array}{l}\text { Various activity offers, especially } \\
\text { online, can be participated more } \\
\text { efficiently from home at no cost. }\end{array}$ & $\begin{array}{l}\text { It encourages the desire } \\
\text { to join an activity. }\end{array}$ \\
\hline $\begin{array}{l}\text { I am active in student } \\
\text { organization activities. }\end{array}$ & $\begin{array}{l}\text { Talents can be channeled by } \\
\text { becoming a student organization } \\
\text { administrator. }\end{array}$ & $\begin{array}{l}\text { It encourages the desire } \\
\text { to join an organization. }\end{array}$ \\
\hline $\begin{array}{l}\text { I feel that there is a real } \\
\text { relationship between } \\
\text { character and the desire to } \\
\text { work. }\end{array}$ & $\begin{array}{l}\text { Good attitudes and behavior make } \\
\text { them aware that they are not limited } \\
\text { to lectures but activities outside of } \\
\text { lectures. }\end{array}$ & $\begin{array}{l}\text { Students with character } \\
\text { are aware of } \\
\text { achievements. }\end{array}$ \\
\hline
\end{tabular}

\section{Discussion}

In this study, the social culture in terms of ethics and norms integrated into the implementation of higher education is carried out in habituation in campus life. Integration of ethics and norms movement is through verbal and written messages using various media devices. Written attributes are installed in meeting rooms, student secretariats, lecture halls, and various online media. The selection of online media used in distance learning programs considers the ease of access (Baltà-Salvador et al., 2021; Jiang et al., 2021; Schmitz et al., 2021). Messages of character habituation in remote online activities are carried out through writing on websites, social media, backdrops, backgrounds, leaflets, and verbally delivered by lecturers in learning. The selected media considers what is often used when interacting remotely with students. Media that students often access, such as websites, is the right choice as long as activities are carried out over long distances due to the Covid-19 pandemic (Batubara \& Batubara, 2020; Shodiq \& Zainiyati, 2020).

Measurement of students' character through self-assessment is most rationally carried out during remote activities. The chance of students communicating when doing the assessment is also small because they are not together in one room. Students always carry out habituation in praying when starting the lecture or activities because no students do not do this habituation from the data. However, it was different when ending the lecture. It was confirmed that there were still students who did not pray. From the interviews, the reasons for not praying are that they are often accidentally signed out from the platform, or the network quality was unstable before the lecture was over. Some participants felt inactive during the guidance with the academic advisor. Online meetings through available applications tend to be short for various reasons, including saving mobile data. Network constraints are the main factor in obstacles in remote activities (Bonotti \& Zech, 2021; Gesú \& González, 2020). The findings of this study confirm how vital the operational standards of distance lectures and activities are. Meetings through online applications must be coordinated well if to maintain the habituation of the students' characters.

In this study, the habituation of students with character is to build students' awareness about their status as students (Damanik \& Setiawan, 2016; Nisa \& Wuryandani, 2018). There is awareness to study diligently so that the achievement index is good, awareness to compete so that they have competitiveness, awareness to participate in non-academic activities to 
channel interests and talents, and encourage leadership through activeness in student organizations. Awareness of achievement as a self-strength must be triggered by its emergence through various stimuli of learning activities (Backfisch et al., 2020; Calafato, 2020; Lothian et al., 2020). According to Picture 4, the average student achievement index is 3.28 from the range of 0.00 to 4.00 , which means it is in a good category. The number of students who participate in the delegation and are active in organizations is quite a lot. Research findings show that character habituation has a contribution in building students' awareness to have achievements. Initially, the character is needed so that students can follow the learning process well (Muhtar \& Dallyono, 2020; Torimtubun et al., 2020). However, today's character formation in the millennial era with social media's extensive influence makes character needed more broadly. The development of productive student character is to increase the value of graduates. The world of work in recruiting employees is not limited to requiring scientific competence but soft skills. Graduates with entrepreneurial talent also need soft skills to build a business in the digital era. With high competence and adaptive ability to apply values and norms, it is expected that graduates will be more competitive and have high competitiveness. The findings of this study become suggestions for universities that initially found it difficult to measure students' character. Various forms of students' character development activities are of no value if measurements are not taken.

\section{CONCLUSION}

Conclusions should, rather than just repeating results, state well-articulated outcomes of the study and briefly suggest future lines of research in the area based on findings reported in the paper.

\section{REFERENCES}

Abdullah, B., Radiansyah, R., \& Akbar, A. (2015). Pendidikan Karakter Di Madrasah Aliyah $\begin{array}{lllll}\text { Negeri (Man) } 2 \text { Banjarmasin. Inferensi, } & \text { 9(2), } & 537 .\end{array}$ https://doi.org/10.18326/infs13.v9i2.537-560.

Amran, A., Jasin, I., Perkasa, M., Satriawan, M., Irwansyah, M., \& Erwanto, D. (2020). Implementation of education for sustainable development to enhance Indonesian golden generation character. Journal of Physics: Conference Series, 1521(4), 1-5. https://doi.org/10.1088/1742-6596/1521/4/042102.

Awidi, I. T., Paynter, M., \& Vujosevic, T. (2019). Facebook group in the learning design of a higher education course: An analysis of factors influencing positive learning $\begin{array}{lllll}\text { experience for students. Computers \& Education, } 129 . & .\end{array}$ https://doi.org/10.1016/j.compedu.2018.10.018.

Backfisch, I., Lachner, A., Hische, C., Loose, F., \& Scheiter, K. (2020). Professional knowledge or motivation? Investigating the role of teachers' expertise on the quality of technology-enhanced lesson plans. Learning and Instruction, 66. https://doi.org/10.1016/j.learninstruc.2019.101300.

Baltà-Salvador, R., Olmedo-Torre, N., \& Peña, M. (2021). Academic and emotional effects of online learning during the COVID-19 pandemic on engineering students. Educ Inf Technol, 1(1). https://doi.org/10.1007/s10639-021-10593-1.

Batubara, H. H., \& Batubara, D. S. (2020). Penggunaan Video Tutorial Untuk Mendukung Pembelajaran Daring Di Masa Pandemi Virus Corona. Muallimuna: Jurnal Madrasah Ibtidaiyah, 5(2), 21. https://doi.org/10.31602/muallimuna.v5i2.2950.

Bervell, B., \& Arkorful, V. (2020). LMS-Enabled Blended Learning Utilization in Distance Tertiary Education: Establishing the Relationships Among Facilitating Conditions, 
Voluntariness of Use and Use Behaviour. International Journal of Educational Technology in Higher Education, 17(1), 6. https://doi.org/10.1186/s41239-020-01839.

Bonotti, \& Zech. (2021). The Human, Economic, Social, and Political Costs of COVID-19. Palgrave Macmillan, Singapore. https://doi.org/10.1007/978-981-33-6706-7_1.

Calafato, R. (2020). Learning Arabic in Scandinavia: Motivation, metacognition, and autonomy. Lingua, 246, 102943. https://doi.org/10.1016/j.lingua.2020.102943.

Chen, Y., Mayall, H. J., York, C. S., \& Smith, T. J. (2019). Parental perception and English Learners' mobile-assisted language learning: An ethnographic case study from a technology-based Funds of Knowledge approach. Learning, Culture and Social Interaction, 22. https://doi.org/10.1016/j.lcsi.2019.100325.

Choli, I. (2020). Problematika Pendidikan Karakter Pendidikan Tinggi. Tahdzib Akhlaq, 5(1). https://doi.org/10.34005/tahdzib.v3i1.831.

Creswell, J., \& Pioano Clark, V. (2007). Introducing a mixed method design. Designing and Conducting Mixed Methods Research, 58-89.

Damanik, M. R., \& Setiawan, D. (2016). Pengembangan Penilaian Autentik Berbasis Karakter Pada Ranah Keterampilan Di Fakultas Ilmu Sosial Universitas Negeri Medan. Jurnal Pendidikan Ilmu-Ilmu Sosial, $8(2)$. https://doi.org/10.24114/jupiis.v8i2.5150.

Darma, Y., Susiaty, \& Fitriawan. (2018). Pendidikan Karakter dalam Pembelajaran pada Mahasiswa Calon Guru Matematika. Jurnal SAP, 3(2). https://doi.org/10.30998/sap.v3i2.3029.

Fahmy, R., Bachtiar, N., Rahim, R., \& Malik, M. (2015). Measuring Student Perceptions to Personal Characters Building in Education: An Indonesian Case in Implementing New Curriculum in High School. Procedia - Social and Behavioral Sciences, 211. https://doi.org/10.1016/j.sbspro.2015.11.112.

Fitriani, S. (2019). Pendidikan Karakter Sebagai Upaya Menciptakan Akhlak Mulia Siswa Sekolah Dasar. ELSE (Elementary School Education Journal): Jurnal Pendidikan Dan Pembelajaran Sekolah Dasar, 3(2), 229-238. https://doi.org/10.30651/else.v3i2.3011.

Gesú, D., \& González. (2020). The Imposed Online Learning and Teaching During COVID19 Times. Cultural Psychology of Education, 13(1). https://doi.org/10.1007/978-3030-63157-4_11.

Göthberg, M. (2019). Cultivation of a deceiver - The emergence of a stage character in a student theatre production. Learning, Culture and Social Interaction, 22. https://doi.org/10.1016/j.lcsi.2019.02.005.

Handoyo, L. D. (2014). Menumbuhkembangkan Karakter Mahasiswa melalui ServiceLearning Program di Mata Kuliah Ilmu Gizi dan Kesehatan. Jurnal Kependidikan Widya Dharma, 25(2). https://ejournal.usd.ac.id/index.php/WidyaDharma/article/view/828.

Hartini, S., S., Firdausi, Misbah, \& Sulaeman. (2018). The Development of Physics Teaching Materials Based on Local Wisdom to Train Saraba Kawa Characters. Jurnal Pendidikan IPA Indonesia, 7(2). https://doi.org/10.15294/jpii.v7i2.14249.

Harzer, C. (2016). The eudaimonics of human strengths: The relations between character strengths and well-being. In Springer International Publishing. In Vittersø, J. (Ed.) Handbook of Eudaimonic Well-Being.

Hasanah. (2013). Implementasi Nilai-Nilai Karakter Inti di Perguruan Tinggi. Jurnal Pendidikan Karakter, 2(1). https://doi.org/10.21831/jpk.v2i2.1439.

Hulukati, W., \& Maryam, R. (2020). Instrumen Evaluasi Karakter Mahasiswa Program Pendidikan Guru Pendidikan Anak Usia Dini. Jurnal Obsesi Jurnal Pendidikan Anak 
Usia Dini, 4(2). https://doi.org/10.31004/obsesi.v4i2.468.

Ibnu, M., \& Syukri, I. (2021). Pembentukan Karakter Siswa Selama Melakukan Pembelajaran Jarak Jauh di Kelurahan Pamoyanan. Educivilia, 2(1). https://doi.org/10.30997/ejpm.v2i1.3615.

Jiang, H., Islam, A. Y. M. A., \& Gu, X. et al. (2021). Online learning satisfaction in higher education during the COVID-19 pandemic: A regional comparison between Eastern and Western Chinese universities. Educ Inf Technol, 1(1). https://doi.org/10.1007/s10639-021-10519-X.

Kim, G., Ko, Y., \& Lee, H. (2020). The Effects of Community-Based Socioscientific Issues Program (SSI-COMM) on Promoting Students' Senseof Place and Character as Citizens. Int J of Sci and Math Educ, 18(1). https://doi.org/10.1007/s10763-01909976-1.

Lavy, S. (2019). A Review of Character Strengths Interventions in Twenty-First-Century Schools: their Importance and How they can be Fostered. Applied Research Quality Life, 1(1). https://doi.org/10.1007/s11482-018-9700-6.

Lestari, N., \& Harjono, N. (2021). Pengembangan Instrumen Penilaian Karakter PPK Aspek Kemandirian Pada Siswa SD Kelas 4. MIMBAR PGSD Undiksha, 9(1). https://doi.org/10.23887/jjpgsd.v9i1.33379.

Lothian, Akcayir, Sparrow, Mcleod, \& Demmans. (2020). SoundHunters: Increasing Learner Phonological Awareness in Plains Cree. Lecture Notes in Computer Science, 12163. https://doi.org/10.1007/978-3-030-52237-7_28.

Monitorir, R. (2020). Dampak Pandemi Covid-19 Terhadap Kepuasan Pembelajaran Jarak Jauh. Jurnal Inovasi Teknologi Pendidikan, 7(1). https://doi.org/10.21831/jitp.v7i1.32771.

Muhtar, T., \& Dallyono, R. (2020). Character Education From the Perspectives of Elementary School Physical Education Teachers. Jurnal Cakrawala Pendidikan, 39(2), 395-408. https://doi.org/10.21831/cp.v39i2.30647.

Mulyono, H., Suryoputro, G., \& Jamil, S. R. (2021). The application of WhatsApp to support online learning during the COVID-19 pandemic in Indonesia. Heliyon, 7(8), e07853. https://doi.org/10.1016/j.heliyon.2021.e07853.

Ningsih, D. P., \& Maulida, I. (2019). Implementasi Kurikulum 2013 Dalam Membentuk Karakter Siswa Pada Pembelajaran Tematik Integratif Kelas IV di SDN I Gapuk. Jurnal Pendidikan, 3(1). https://doi.org/10.36312/jisip.v3i1.988.

Nisa, \& Wuryandani. (2018). Perancangan Buku Cerita Pop-up Berbasis Karakter untuk Menanamkan Karakter Peduli Sosial Anak Usia Dini. Pedagogia: Jurnal Pendidikan, 7(2), 159-166. https://doi.org/10.21070/pedagogia.v7i2.1563.

Nurgiyantoro, B., \& Anwar, E. (2013). Prioritas Penentuan Nilai Pendidikan Karakter dalam Pembelajaran Sastra Remaja. Cakrawala Pendidikan, 3. https://doi.org/10.21831/cp.v3i3.1626.

Nurtanto, M., Fawaid, M., \& Sofyan, H. (2020). Problem Based Learning (PBL) in Industry 4.0: Improving Learning Quality through Character-Based Literacy Learning and Life Career Skill (LL-LCS). Journal of Physics: Conference Series, 1573(1), 0-10. https://doi.org/10.1088/1742-6596/1573/1/012006.

Schmitz, S. M., Schipper, S., \& Lemos, M. (2021). Development of a tailor-made surgical online learning platform, ensuring surgical education in times of the COVID19 pandemic https://doi.org/. BMC Surg 21, 196. https://doi.org/10.1186/s12893-02101203-5.

Serbin, K. S., Sánchez, B. J., Truman, J. V., \& Watson, K. L. (2020). Characterizing quantum physics students' conceptual and procedural knowledge of the characteristic equation. The Journal of Mathematical 58. 
https://doi.org/10.1016/j.jmathb.2020.100777.

Shodiq, I. J., \& Zainiyati, H. S. (2020). Pemanfaatan Media Pembelajaran E-Learning Menggunakan Whastsapp Sebagai Solusi Ditengah Penyebaran Covid-19 Di Mi Nurulhuda Jelu. Al-Insyiroh: Jurnal Studi Keislaman, 6(2), 144-159. https://doi.org/10.35309/alinsyiroh.v6i2.3946.

Stojanović, J., Petkovic, D., Alarifi, I. M., Cao, Y., Denic, N., \& Ilic, J. (2021). Application of distance learning in mathematics through adaptive neuro-fuzzy learning method. $\begin{array}{llll}\text { Computers } \quad \& \quad \text { Electrical } & 93 .\end{array}$ https://doi.org/10.1016/j.compeleceng.2021.107270.

Suastra, I. W., Jatmiko, B., Ristiati, N. P., \& Yasmini, L. P. B. (2017). Developing characters based on local wisdom of bali in teaching physics in senior high school. Jurnal Pendidikan IPA Indonesia, 6(2), 306-312. https://doi.org/10.15294/jpii.v6i2.10681.

Suhaida, D., \& Idham, A. (2018). Peran Dosen dalam Mengembangkan Karakter Mandiri pada Mahasiswa. SOSIAL HORIZON: Jurnal Pendidikan Sosial, 5(1). https://doi.org/10.31571/sosial.v5i1.866.

Susanti, R. (2013). Penerapan Pendidikan Karakter di Kalangan Mahasiswa. Jurnal AlTa'lim, 1(6). https://doi.org/10.15548/jt.v20i3.46.

Sutijan, S., Makhfud, H., Lestari, L., \& Chumdari, C. (2015). Pengembangan Instrumen Penilaian Pendidikan Karakter Terpadu. Paedagogia, 18(2). https://jurnal.fkip.uns.ac.id/index.php/paedagogia/article/view/7517/0.

Taufiqurrahman. (2018). Pembentukan Karakter Mahasiswa dalam Sistem Pendidikan Tinggi Islam. TADRIS (Journal of Education and Teacher Training), 13(1). https://doi.org/10.19105/tjpi.v13i1.1716.

Torimtubun, H., Arifin, S., \& Yarnest. (2020). Analysis of the Influence of Character, Compensation and Teaching Experience on Teacher Professionalism in the Kepulauan Tanimbar Regency of Indonesia. International Journal of Advances in Scientific Research and Engineering, 06(08), 74-81. https://doi.org/10.31695/ijasre.2020.33863.

Wahab, A. (2016). Peran Perguruan Tinggi dalam Membangun Karakter Generasi Muda. Jurnal Pendidikan Geosfer, 1(2). https://doi.org/10.23701/jpg.v1i2.17436.

Wahono, M. (2018). Pendidikan Karakter: Suatu Kebutuhan bagi Mahasiswa di Era Milenial. Integralistik, 2(1). https://doi.org/10.15294/integralistik.v29i2.16696.

Warsito, S., Asrowi, A., Mulyoto, M., \& Sri, A. (2016). The Effectiveness of IPS-based Contextual Learning to Improve Students Character. International Journal of Active Learning, 1(2). https://journal.unnes.ac.id/nju/index.php/ijal/article/view/7740.

Wayan, I. (2020). Pendidikan Karakter pada Pembelajaran Daring. Indonesian Values and Character Education Journal, 3(1). https://doi.org/10.23887/ivcej.v3i1.27830.

Winther-Lindqvist, D. A. (2020). Caring well for children in ECEC from a wholeness approach - The role of moral imagination. Learning, Culture and Social Interaction, 1. https://doi.org/10.1016/j.lcsi.2020.100452. 